\section{Cureus}

Received 03/04/2019

Review began 03/07/2019

Review ended 04/12/2019

Published 04/16/2019

\section{(c) Copyright 2019}

Huang et al. This is an open access article distributed under the terms of the Creative Commons Attribution License CC-BY 3.0., which permits unrestricted use, distribution, and reproduction in any medium, provided the original author and source are credited.

\title{
Early Initiation of Tocilizumab in Clinically Isolated Aortitis
}

\author{
Irvin J. Huang ${ }^{1}$, Trevor Pugh ${ }^{1}$, Jean Liew ${ }^{2}$ \\ 1. Internal Medicine, University of Washington, Boise, USA 2. Rheumatology, University of Washington, \\ Seattle, USA
}

$\square$ Corresponding author: Jean Liew, liew.jw@gmail.com

Disclosures can be found in Additional Information at the end of the article

\section{Abstract}

Clinically isolated aortitis can arise from infectious or inflammatory etiologies. Glucocorticoids are the first-line therapy for inflammatory causes of aortitis such as large-vessel vasculitis. However, prolonged steroids use is associated with numerous side effects. We present a case of a 60-year-old woman with clinically isolated aortitis who received early treatment with tocilizumab to avoid prolonged steroid use.

Categories: Internal Medicine, Rheumatology

Keywords: tocilizumab, vasculitis, aortitis, steroids, glucocorticoids

\section{Introduction}

Aortitis can arise from infectious or inflammatory etiologies. Corticosteroids are the mainstay therapy in inflammatory conditions such as large vessel vasculitis [1-2]. We present a case of clinically isolated aortitis due to large vessel vasculitis, which was treated with the early initiation of tocilizumab and allowed for a rapid glucocorticoid taper.

\section{Case Presentation}

A 60-year-old woman with a past medical history of remote breast cancer and depression was evaluated at an outside hospital emergency department for high fevers, myalgia, fatigue, productive cough, and chills. She had a recent gastrointestinal illness after eating fish and salad at a new restaurant, which spontaneously resolved. Two days afterward, she began experiencing fevers associated with fatigue and drenching sweats that occurred twice daily and were not alleviated with antipyretics. Additionally, she reported headaches, sinus congestion, and a sore throat that resolved with antibiotics prescribed for sinusitis.

Her vital signs were significant for a temperature of $39.4^{\circ} \mathrm{C}$. Her physical exam did not disclose temporal tenderness, asymmetrical pulses, conjunctival injection, oral ulcers, cervical lymphadenopathy, or rashes. Her initial laboratory studies were remarkable for a white blood cell count (WBC) of 21,700/uL, C-reactive protein (CRP) of $26 \mathrm{mg} / \mathrm{L}$, and erythrocyte sedimentation rate (ESR) of $74 \mathrm{~mm} / \mathrm{hr}$. Computed tomography (CT) of the chest with contrast showed diffuse, abnormal soft tissue around the ascending aorta and aortic arch with fat stranding, which was consistent with aortitis (Figure 1). She was transferred to our hospital in Seattle, Washington, for rheumatological management of aortitis. 


\section{Cureus}

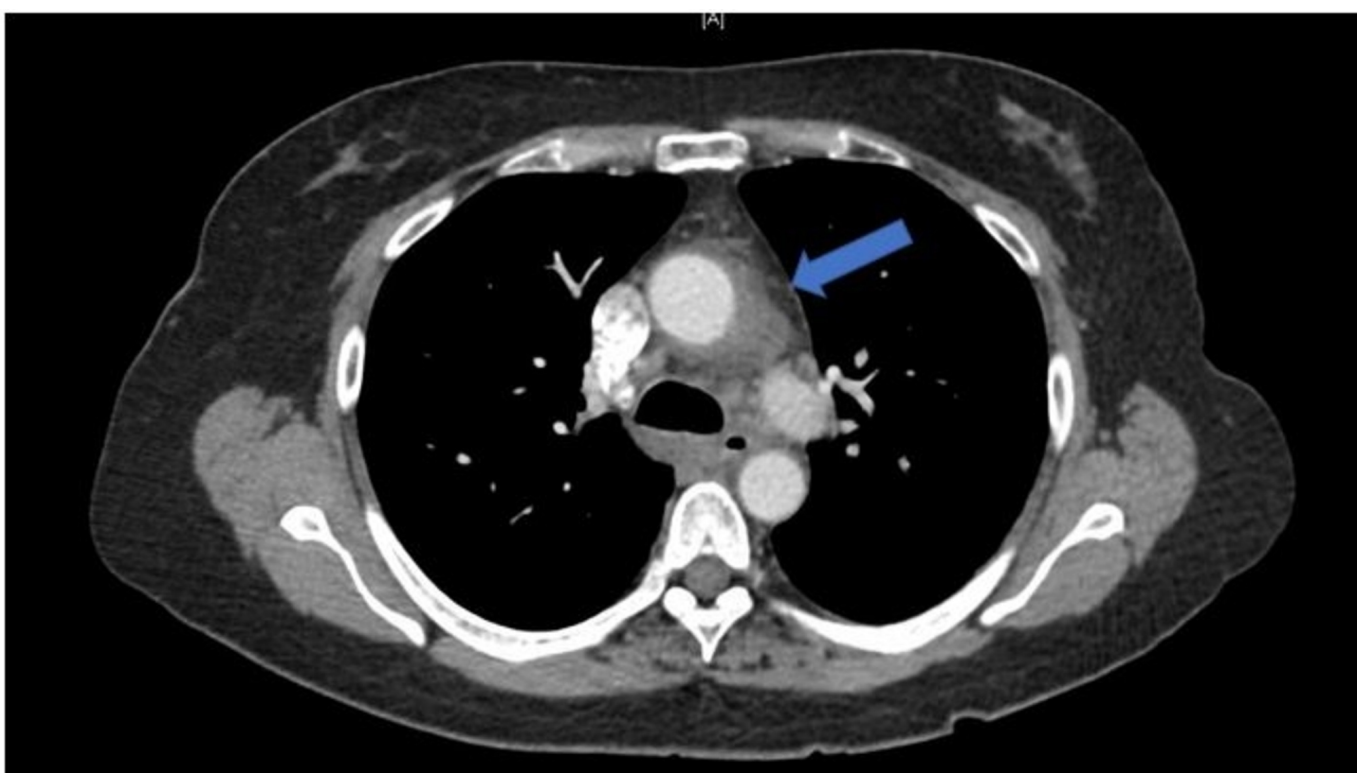

\section{FIGURE 1: Aortitis on CT chest}

Computed tomography (CT) chest without contrast obtained during the March 2018 admission for fevers and constitutional symptoms. Diffuse fat stranding is seen surrounding the ascending aorta and aortic arch (arrow), consistent with aortitis.

On repeat laboratory evaluation, WBC was 18,000/uL, ESR was $105 \mathrm{~mm} / \mathrm{hr}$, and CRP was 319.7 $\mathrm{mg} / \mathrm{L}$. Rheumatoid factor, anti-cyclic citrullinated peptide, antinuclear antibody, anti-doublestranded DNA, antineutrophil cytoplasmic antibody, and serum IgG4 subclasses were unrevealing. Her persistent double-quotidian fevers, elevated inflammatory markers, and aortic findings on CT were concerning for an infectious versus inflammatory aortitis. Potential infectious etiologies of aortitis included tuberculosis (TB), human immunodeficiency virus (HIV), syphilis, and enteric pathogens such as Salmonella. Serologic and fecal testing for these infectious etiologies were negative.

The differential for noninfectious, inflammatory conditions included giant cell arteritis (GCA), Takayasu's arteritis, anti-neutrophilic cytoplasmic autoantibody (ANCA) vasculitis, systemic lupus erythematosus (SLE), rheumatoid arthritis (RA), immunoglobulin G4 (IgG4)-related disease, and Erdheim-Chester disease. Her lack of suggestive clinical history and negative serologies made RA, SLE, and ANCA vasculitis unlikely. Her high fevers and significantly elevated inflammatory markers were less suggestive of IgG4-related disease or ErdheimChester disease, and imaging did not demonstrate a suggestive pattern of involvement in other organs. There was also no evidence of malignancy on axial imaging.

The patient was diagnosed with isolated aortitis given her presenting constitutional symptoms, significantly elevated inflammatory markers, and CT chest finding of diffuse fat stranding surrounding the ascending aorta and aortic arch. Her isolated aortitis may be a limited variant of GCA or Takayasu's arteritis although she did not have the classical symptoms of either [3]. Ultrasound of the temporal arteries and vessels of the upper extremities did not demonstrate a characteristic "halo sign," and temporal artery biopsy was deferred given the lack of suggestive clinical features of GCA. The patient was initiated on prednisone therapy at $60 \mathrm{mg}$ daily with a taper over four months. However, due to steroid intolerance, including fatigue and poor sleep, she was started on weekly tocilizumab $162 \mathrm{mg}$ subcutaneous injections within one month of diagnosis. Her elevated inflammatory markers and symptoms resolved quickly and she remains in remission at 10 months of follow-up. Follow-up CT chest demonstrated the attenuation of 


\section{Cureus}

inflammation around the aorta (Figure 2). Even though pseudoaneurysms were noted, these were felt to be likely sequelae of the initial episode. They were stable on further repeat imaging. We plan to continue with tocilizumab for at least 18 months, although the optimal duration of therapy is unclear [4].

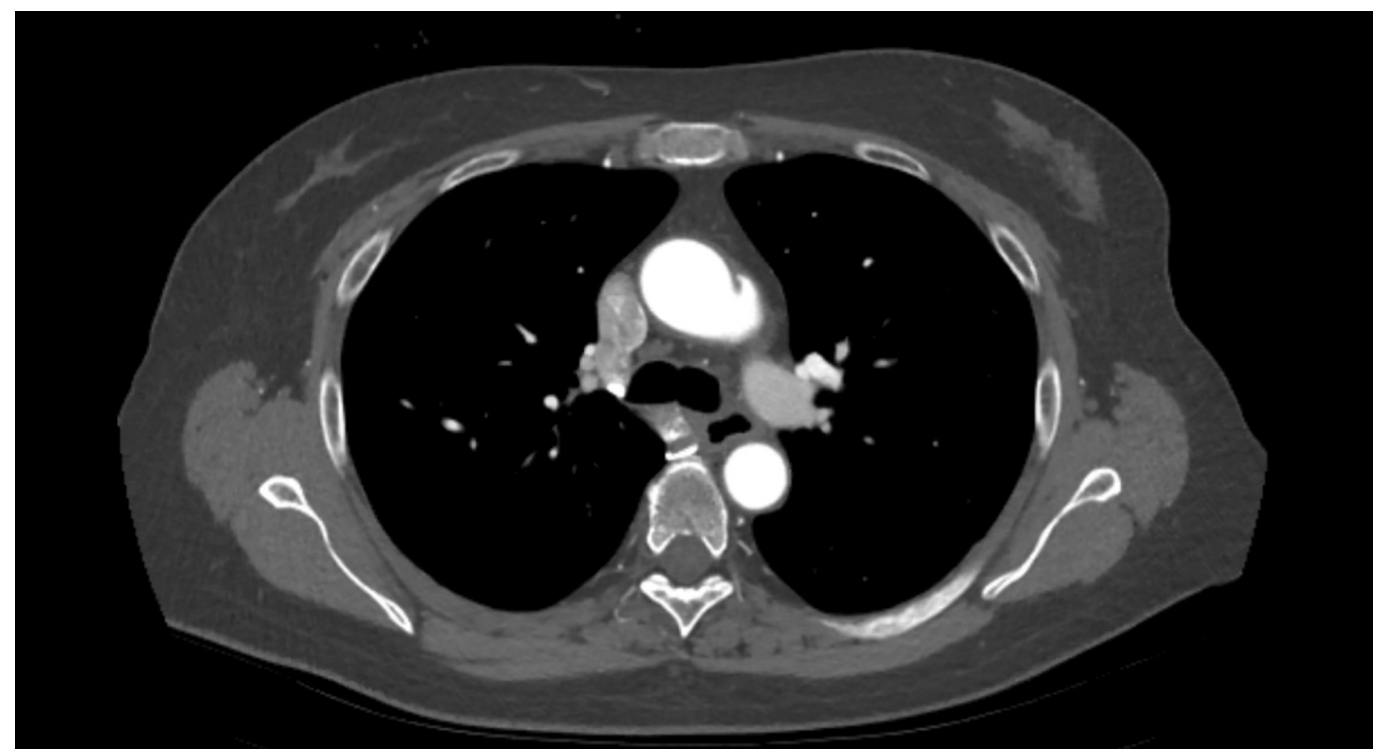

\section{FIGURE 2: Follow-up CT chest}

Follow-up computed tomography (CT) chest demonstrating the attenuation of inflammation. The pseudoaneurysms were believed to be sequelae of the initial episode. They have been stable on further repeat imaging.

\section{Discussion}

Clinically isolated aortitis can be a manifestation of either infectious or noninfectious inflammatory etiologies [5]. Inflammatory causes include GCA, Takayasu's arteritis, and IgG4-related disease more commonly and SLE, RA, Cogan's syndrome, Behçet's disease, relapsing polychondritis, and ankylosing spondylitis more rarely. According to the 2012 Chapel Hill Consensus Conference, isolated aortitis is classified as a single organ vasculitis, although they may just be limited variants of GCA or Takayasu's arteritis [3]. Glucocorticoids are the firstline therapy for large-vessel vasculitis, although their use is associated with potential side effects that increase with higher cumulative doses. Tocilizumab, an interleukin 6 (IL-6) receptor monoclonal antibody, was approved for the treatment of GCA after a randomized trial found significantly higher rates of sustained remission in the tocilizumab-treated group as compared to the group receiving glucocorticoids alone [4]. In case series and case reports of aortitis secondary to underlying GCA, Takayasu's arteritis, ANCA vasculitis, and relapsing polychondritis, tocilizumab has been used successfully (Table 1) [6-13]. This significant response to tocilizumab suggests that the IL-6 cytokine is involved as a central component in the development of aortitis independent of the concurrent disease syndrome. Additionally, the patients' improvement on tocilizumab in our literature review appears to be unrelated to previous therapies administered. In our case, tocilizumab was started early in the course of disease with a rapid and sustained response.

\section{Tocilizumab} therapy
Outcome 


\section{Cureus}

\begin{tabular}{|c|c|c|c|c|c|}
\hline & & & & regimen & \\
\hline $\begin{array}{l}\text { Narshi C. } \\
\text { et al. [11] }\end{array}$ & 43 & Female & $\begin{array}{l}\text { Relapsing polychondritis with collapse of the nasal } \\
\text { bridge, recurrent ocular inflammation, bilateral auricular } \\
\text { and costochondritis followed by aortitis. Previously on } \\
\text { corticosteroids and IFX, followed by ADA which was } \\
\text { increased to } 10 \mathrm{mg} / \mathrm{kg} \text { with MTX and deflazacort }\end{array}$ & $\begin{array}{l}8 \mathrm{mg} / \mathrm{kg} \text { in } \\
\text { combination } \\
\text { with } \\
\text { deflazacort }\end{array}$ & $\begin{array}{l}18 \text { month } \\
\text { follow-up with } \\
\text { down-titration of } \\
\text { deflazacort to } 6 \\
\text { mg daily }\end{array}$ \\
\hline $\begin{array}{l}\text { Kawai, M. } \\
\text { et al. [10\} }\end{array}$ & 29 & Female & $\begin{array}{l}\text { Relapsing polychondritis with auricular, nasal and } \\
\text { costochondral pain with thickening of laryngotracheal } \\
\text { walls with severe airway narrowing and bronchial wall } \\
\text { thickening. Previously on CyA, tacrolimus, CYC and IFX } \\
3 \mathrm{mg} / \mathrm{kg}\end{array}$ & $\begin{array}{l}8 \mathrm{mg} / \mathrm{kg} \text { in } \\
\text { combination } \\
\text { with } \\
\text { prednisone } 40 \\
\mathrm{mg}\end{array}$ & $\begin{array}{l}9 \text { month follow- } \\
\text { up with } \\
\text { decrease in } \\
\text { prednisone to } \\
15 \mathrm{mg} \text { and } 10 \\
\mathrm{mg} \text { in one year }\end{array}$ \\
\hline $\begin{array}{l}\text { Kawai, M. } \\
\text { et al. [10] }\end{array}$ & 52 & Male & $\begin{array}{l}\text { Relapsing polychondritis with airway narrowing and } \\
\text { airway thickening. Previously on MTX } 7.5-10 \mathrm{mg} / \text { week } \\
\text { and prednisolone } 15-30 \mathrm{mg} / \text { day }\end{array}$ & $\begin{array}{l}8 \mathrm{mg} / \mathrm{kg} \text { in } \\
\text { combination } \\
\text { with } \\
\text { prednisolone } \\
15 \mathrm{mg}\end{array}$ & $\begin{array}{l}5 \text { months } \\
\text { follow-up, } \\
\text { prednisolone } \\
\text { decreased to } \\
10 \mathrm{mg}\end{array}$ \\
\hline $\begin{array}{l}\text { Stael, R. } \\
\text { et al. [9] }\end{array}$ & 25 & Male & $\begin{array}{l}\text { Relapsing polychondritis with asymmetrical oligoarthritis, } \\
\text { scleritis and endocarditis. Previously on SSZ } 3 \mathrm{~g} \text { daily } \\
\text { and piroxicam } 20 \mathrm{mg} \text {, transitioned to ETN and } \\
\text { developed endocarditis; then IFX and MTX } 15 \mathrm{mg} \text { with } \\
\text { prednisolone } 20 \mathrm{mg} \text {. }\end{array}$ & $\begin{array}{l}8 \mathrm{mg} / \mathrm{kg} \text { in } \\
\text { combination } \\
\text { with } \\
\text { prednisolone } \\
10 \mathrm{mg} \text { and } \\
\text { MTX } 15 \mathrm{mg} \\
\text { weekly }\end{array}$ & $\begin{array}{l}5 \text { month follow- } \\
\text { up, developed } \\
\text { SVT, markedly } \\
\text { improved } \\
\text { symptoms in } \\
\text { one year }\end{array}$ \\
\hline $\begin{array}{l}\text { Ashraf, } \\
\text { F.A.M. et } \\
\text { al. [12] }\end{array}$ & 62 & Male & $\begin{array}{l}\text { Polymyalgia rheumatica with fatigue, night sweats, } \\
\text { aortic valve insufficiency, aortitis with aortic aneurysm. } \\
\text { Previously on methylprednisolone }\end{array}$ & Unspecified & $\begin{array}{l}\text { Inflammatory } \\
\text { markers } \\
\text { continued to be } \\
\text { normal at time } \\
\text { of publication }\end{array}$ \\
\hline $\begin{array}{l}\text { Elourimi, } \\
\text { G. et al. } \\
\text { [8] }\end{array}$ & 59 & Female & $\begin{array}{l}\text { Relapsing polychondritis with nasal, bilateral auricular } \\
\text { chondritis with pericarditis, episcleritis. Previously on } \\
\text { prednisone } 1 \mathrm{mg} / \mathrm{kg} \text { daily, gradually tapered to } 5 \mathrm{mg} / \mathrm{day} \text {, } \\
\text { episcleritis recurred. }\end{array}$ & $\begin{array}{l}8 \mathrm{mg} / \mathrm{kg} \text { with } \\
\text { prednisone } 70 \\
\mathrm{mg}\end{array}$ & $\begin{array}{l}3 \text { month follow- } \\
\text { up with } \\
\text { prednisone } \\
\text { decreased to } 5 \\
\text { mg }\end{array}$ \\
\hline $\begin{array}{l}\text { Loricera, } \\
\text { J. et al. [6] }\end{array}$ & 7 & Female & $\begin{array}{l}\text { Takayasu's arteritis. Previously on MTX, CYC, MMF, } \\
\text { ETN, IFX, Prednisone } 30 \mathrm{mg}\end{array}$ & $\begin{array}{l}8 \mathrm{mg} / \mathrm{kg} \text { with } \\
\text { prednisone } 30 \\
\mathrm{mg}\end{array}$ & $\begin{array}{l}24 \text { month } \\
\text { follow-up, } \\
\text { prednisone } \\
\text { decreased to } 0 \\
\text { mg }\end{array}$ \\
\hline $\begin{array}{l}\text { Loricera, } \\
\text { J. et al. [6] }\end{array}$ & 57 & Female & Takayasu's arteritis. Previously on CYC & $\begin{array}{l}8 \mathrm{mg} / \mathrm{kg} \text { with } \\
\text { prednisone } 45 \\
\mathrm{mg}\end{array}$ & $\begin{array}{l}18 \text { month } \\
\text { follow-up, } \\
\text { prednisone } \\
\text { decreased to } 5 \\
\text { mg }\end{array}$ \\
\hline & & & & & 12 month \\
\hline
\end{tabular}




\section{Cureus}

Loricera, 26 Female Takayasu's arteritis. Previously on MTX, AZA, IFX

J. et al. [6]

Female Takayasu's arteritis. Previously on MTX, AZA, IFX

Loricera,

J. et al. [6] 16 Female Takayasu's arteritis. Previously on MTX, ADA

Loricera,

J. et al. [6]

Female

Tak

akayasu's arteritis. Previously on MTX, AZA, MMF, IFX

Loricera,

J. et al. [6] 41

Female

Takayasu's arteritis. Previously on MTX, ADA, IFX

Loricera,

J. et al. [6] 46

Female

Takayasu's arteritis. Previously on MTX

$\begin{array}{ll}\text { Loricera, } & \text { Female Giant cell arteritis. Previously on MTX } \\ \text { J. et al. [6] }\end{array}$

Loricera,

J. et al. [6] 59 Female Giant cell arteritis. Previously on MTX

Loricera,

J. et al. [6] 65 Female Giant cell arteritis. Previously on MTX

Loricera,

J. et al. [6] 67 Female Giant cell arteritis. Previously on MTX

Loricera,

J. et al. [6]

74 Female Giant cell arteritis. Previously on MTX

8mg/kg with
prednisone 50
$\mathrm{mg}$
8mg/kg with
prednisone 50
mg

follow-up,

prednisone

decreased to

$7.5 \mathrm{mg}$

12 month

follow-up,

prednisone

decreased to

$7.5 \mathrm{mg}$

13 month

$8 \mathrm{mg} / \mathrm{kg}$ with follow-up,

prednisone 25 prednisone

$\mathrm{mg}$

decreased to 0

$\mathrm{mg}$

$8 \mathrm{mg} / \mathrm{kg}$ with

prednisone 40

$\mathrm{mg}$

3 month followup, prednisone decreased to $10 \mathrm{mg}$

$8 \mathrm{mg} / \mathrm{kg}$ with prednisone 25 mg

4 month followup, prednisone decreased to 5 $\mathrm{mg}$

$8 \mathrm{mg} / \mathrm{kg}$ with prednisone 10 mg up, prednisone decreased to $2.5 \mathrm{mg}$

16 month

$8 \mathrm{mg} / \mathrm{kg}$ with follow-up, prednisone 60 prednisone $\mathrm{mg}$ decreased to 5 mg

20 month

$8 \mathrm{mg} / \mathrm{kg}$ with prednisone follow-up, $17.5 \mathrm{mg}$ prednisone decreased to 0 $\mathrm{mg}$

$8 \mathrm{mg} / \mathrm{kg}$ with prednisone $10 \mathrm{mg}$

6 month followup, prednisone decreased to 0 mg

11 month follow-up, inflammatory markers undetectable 


\section{Cureus}

Loricera,

J. et al. [6] 64 Female Giant cell arteritis. Previously on MTX

Loricera,

J. et al. [6]

53 Male

Giant cell arteritis. Previously on MTX

Loricera,

J. et al. [6]

50 Female

Relapsing Polychondritis with aortitis. Previously on MTX, CyA, LFN, CYC, IFX

Retroperitoneal fibrosis with aortitis. No previous treatment.

ANCA associated vasculitis with hypertrophic

Takenaka,

K. et al. [7]
$47 \quad$ Female

8mg/kg with
prednisone 15
$\mathrm{mg}$

$8 \mathrm{mg} / \mathrm{kg}$ with

prednisone 30

mg

$8 \mathrm{mg} / \mathrm{kg}$ with
prednisone 30
$\mathrm{mg}$

$8 \mathrm{mg} / \mathrm{kg}$

$400 \mathrm{mg} / \mathrm{month}$

with

prednisolone

$50 \mathrm{mg}$
3 month followup, prednisone decreased to $10 \mathrm{mg}$

5 month followup, prednisone decreased to $10 \mathrm{mg}$

20 month follow-up, prednisone decreased to 5 mg

17 month follow-up.

1 year followup, prednisolone decreased to 4 $\mathrm{mg}$

\section{TABLE 1: Case series of tocilizumab for the treatment of aortitis as the primary presentation of giant cell arteritis, Takayasu's arteritis, polymyalgia rheumatica, relapsing polychondritis, ANCA vasculitis, or retroperitoneal fibrosis}

Abbreviations: MTX: Methotrexate; CYC: Cyclophosphamide; MMF: Mycophenolate mofetil; ETN: Etanercept; IFX: Infliximab; ADA: Adalimumab; CyA: Cyclosporine A; LFN: Leflunomide; SSZ: sulfasalazine; ANCA: Anti-neutrophilic cytoplasmic autoantibody

\section{Conclusions}

Inflammatory aortitis may be the sole presenting manifestation of a large vessel vasculitis. Although steroids are the first-line therapy for a variety of inflammatory conditions that may cause aortitis, their prolonged use is associated with a myriad of side effects. We advocate for the early consideration of tocilizumab for the management of inflammatory aortitis, a potentially life-threatening condition.

\section{Additional Information}

\section{Disclosures}

Human subjects: Consent was obtained by all participants in this study. University of Washington issued approval N/A. IRB approval from the University of Washington is not required for case reports. Conflicts of interest: In compliance with the ICMJE uniform disclosure form, all authors declare the following: Payment/services info: All authors have declared that no financial support was received from any organization for the submitted work. Financial relationships: All authors have declared that they have no financial relationships at present or within the previous three years with any organizations that might have an interest in the submitted work. Other relationships: All authors have declared that there are no other 
relationships or activities that could appear to have influenced the submitted work.

\section{References}

1. Kermani TA, Dasgupta B: Current and emerging therapies in large-vessel vasculitis . Rheumatology. 2018, 57:1513-1524. 10.1093/rheumatology/kex385

2. Proven A, Gabriel SE, Orces C, O’Fallon M, Hunder GG: Glucocorticoid therapy in giant cell arteritis: duration and adverse outcomes. Arthritis Rheum. 2003, 49:703-708.

10.1002/art.11388

3. Jennette JC, Falk RJ, Bacon PA, et al.: 2012 Revised International Chapel Hill Consensus Conference Nomenclature of Vasculitides. Arthritis Rheum. 2013, 65:1-11. 10.1002/art.37715

4. Stone JH, Tuckwell K, Dimonaco S, et al.: Trial of tocilizumab in giant-cell arteritis . N Engl J Med. 2017, 377:317-328. 10.1056/NEJMoa1613849

5. Cinar I, Wang H, Stone JR: Clinically isolated aortitis: pitfalls, progress, and possibilities . Cardiovasc Pathol. 2017, 29:23-32. 10.1016/j.carpath.2017.04.003

6. Loricera J, Blanco R, Castañeda S, et al.: Tocilizumab in refractory aortitis: study on 16 patients and literature review. Clin Exp Rheumatol. 2014, 32:79-89.

7. Takenaka K, Ohba T, Suhara K, Sato Y, Nagasaka K: Successful treatment of refractory aortitis in antineutrophil cytoplasmic antibody-associated vasculitis using tocilizumab. Clin Rheumatol. 2014, 33:287-289. 10.1007/s10067-013-2457-2

8. Elourimi G, Soussan M, Warzocha U, Bugaud H, Dhote R, Abad S: Efficacy of tocilizumab highlighted by FDG-PET/CT in a patient with relapsing polychondritis-associated aortitis. Rheumatol Int. 2017, 37:1931-1935. 10.1007/s00296-017-3832-0

9. Stael R, Smith V, Wittoek R, Creytens D, Mielants H: Sustained response to tocilizumab in a patient with relapsing polychondritis with aortic involvement: a case based review. Clin Rheumatol. 2015, 34:189-193. 10.1007/s10067-014-2670-7

10. Kawai M, Hagihara K, Hirano T, et al.: Sustained response to tocilizumab, anti-interleukin-6 receptor antibody, in two patient with refractory relapsing polychondritis. Rheumatology. 2009, 48:318-319. 10.1093/rheumatology/ken468

11. Narshi CB, Allard SA: Sustained response to tocilizumab, anti-IL-6 antibody, following antiTNF- $\alpha$ failure in a patient with relapsing polychondritis complicated by aortitis. Rheumatology. 2012, 521:952-953. 10.1093/rheumatology/ker451

12. Ashraf FAM, Anjum S, Hussaini A, Fraser A: Refractory PMR with aortitis: lifesaving treatment with anti-IL6 monoclonal antibody (tocilizumab) and surgical reconstruction of the ascending aorta. BMJ Case. 2013, 2013:bcr2013009523. 10.1136/bcr-2013-009523

13. Unizony S, Arias-Urdaneta E, Miloslavsky S, et al.: Tocilizumab for the treatment of largevessel vasculitis (giant cell arteritis, Takayasu arteritis) and polymyalgia rheumatica. Arthritis Care Res. 2012, 64:1720-1729. 10.1002/acr.21750 